\title{
NUTRIENT AND ORGANIC MATTER REMOVAL FROM CHICKEN MANURE LEACHATE USING CHLORELLA SPP.
}

\author{
ZAMFIRA DINCĂ ${ }^{a}$, MARIA-ALEXANDRA HOAGHIA ${ }^{a}$, \\ ANAMARIA-IULIA TÖRÖKa ${ }^{a}$ ENIKO KOVACS ${ }^{a, b}$, OANA CADAR $^{a}$, \\ EMILIA NEAG ${ }^{a *}$, CECILIA ROMAN ${ }^{a}$
}

\begin{abstract}
In the present study, the use of chicken manure leachate $(\mathrm{CML})$ as a nutrient source for the cultivation of Chlorella spp. at laboratory scale was investigated. The concentration of total organic carbon (TOC) and biochemical oxygen demand (BOD) was monitored during 15 days of cultivation in CML. The changes of $\mathrm{pH}$, conductivity, $\mathrm{Cl}^{-}, \mathrm{PO}_{4}{ }^{3-}, \mathrm{SO}_{4}{ }^{2-}, \mathrm{NO}_{2}-$ and $\mathrm{NO}_{3}$ - concentrations were measured during the growth period. The BOD and TOC reduction was $96.4 \%$ and $86.1 \%$, respectively after 15 days of cultivation in CML. The Chlorella spp. biomass cultured in CML had a high protein content compared to the biomass grown in the BG-11 medium. The obtained results suggest the potential use of CML as a nutrient source for the growth of Chlorella spp.
\end{abstract}

Keywords: biomass, chicken manure, microalgae

\section{INTRODUCTION}

The poultry production industry generates large quantities of wastes worldwide. Manure, litter, on-farm mortalities, and hatchery wastes tend to grow if we consider the fivefold increase in poultry production from the last 50 years [1]. With an annual production of 13.3 million tons, the EU is one of the world's leading producers of poultry meat [2]. This exponential growth of the poultry production sector brings into question the issue about the fate of poultry wastes and the disposal ways and strategies [3].

\footnotetext{
a INCDO-INOE 2000, Research Institute for Analytical Instrumentation, 67 Donath Street, 400293 Cluj-Napoca, Romania

b University of Agricultural Sciences and Veterinary Medicine, 3-5 Calea Manastur Street, 400372 Cluj-Napoca, Romania

*Corresponding author: emilia.neag@icia.ro
} 
Poor waste management in the poultry industry can lead over time to pollution and environmental problems, like eutrophication [4]. Increased GHG emissions, deforestation and biodiversity loss are all significant issues that the intensive poultry industry causes [5]. Leachate from poultry manure reach the soil, surface or groundwater causing nitrates and phosphates pollution and environmental contamination with pathogens, such as Enterobacteriaceae or Staphylococcaceae [6]. For this reason, the proper treatment of poultry wastes prior to discharge, as well as the environmentally sustainable management of poultry manure are required. Converting chicken manure from a waste product to a resource is one of the environmentally sustainable measures that can be taken [3].

Chicken manure is rich in both organic and inorganic nutrients and contains high concentrations of nitrogen (eliminated in the form of uric acid), high carbon content, phosphate and potassium [6-8]. Moreover, it contains trace elements, such as Fe, Mg, Mn, S and $\mathrm{Zn}$ for the growth of microalgae [3]. The nutrient composition of poultry manure depends on the age and diet of the flock, the age of the manure and its moisture content [9]. Because of its complex content, chicken manure has a wide range of applications, from its rational application as biofertilizer or as a culture medium for autotrophic organisms, to the production of biogas or bioethanol [10-12]. The use of nutrients from livestock manure for microalgal biomass production received worldwide interest [4], even if there is a lack of information related to the suitability of chicken manure to sustain microalgae growth [3].

Several microalgae species, such as Chlorella spp. or Scenedesmus obliquus are considered proper candidates for cultivation in a manure extract medium, due to their rapid adaptation to various nutritional conditions [3]. Many synthetic culture media are expensive and depletable resources. In addition to the nutritional advantage, the growing medium obtained from chicken manure has an economic and eco-friendly impact on the environment [13].

The purpose of this study was to determine the ability of Chlorella spp. to grow in nutrient-rich sources, such as chicken manure leachate and to reduce the organic matter concentrations.

\section{RESULTS AND DISCUSSION}

\section{Growth of Chlorella spp. in CML}

Figure $1 \mathrm{a}$ and $1 \mathrm{~b}$ illustrate the $\mathrm{pH}$ and conductivity changes, respectively. $\mathrm{pH}$ values fluctuate within a tight range during the Chlorella spp. cultivation. The obtained data revealed that the $\mathrm{pH}$ values (8.2-8.4) slowly increased 
during cultivation. The intracellular metabolic fluxes in algal cells increase the $\mathrm{pH}$ during their photosynthesis, following the $\mathrm{CO}_{2}$ assimilation [14]. During the cultivation of Chlorella spp., the electric conductivity (EC) values slowly decreased by time (Figure $1 \mathrm{~b}$ ).

The TOC and BOD reduction during the cultivation of Chlorella spp. can be observed in Figure 1c and 1d, respectively. The TOC and BOD reduction increased with time. The changes in the TOC reduction ranged between $75 \%$ and $86 \%$, while for BOD between $81 \%$ and $96 \%$ during 15 days of cultivation, showing that the amount of oxidizable pollutants in the water samples was removed with time by the microalgae biomass.

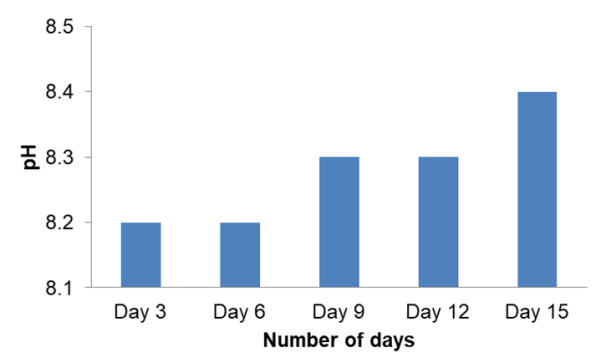

(a)

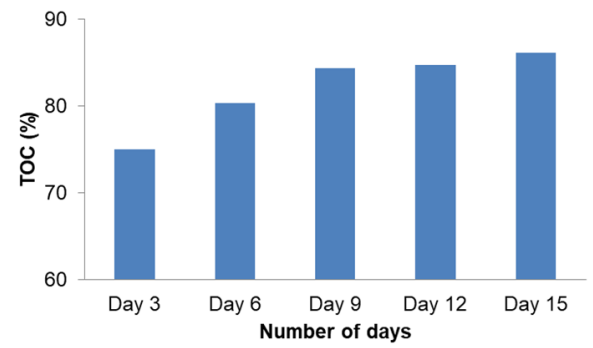

(c)

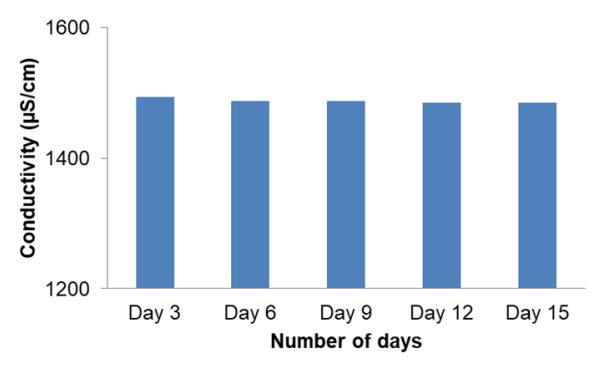

(b)

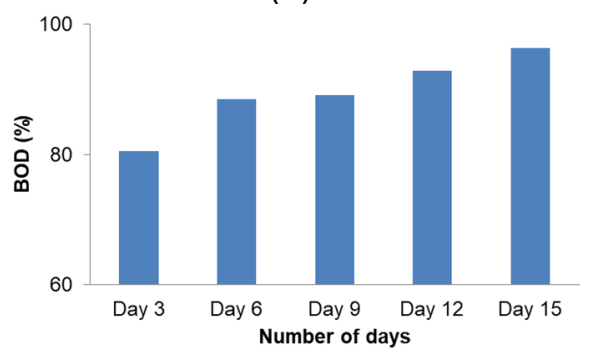

(d)

Figure 1. The $\mathrm{pH}$ and conductivity changes, and TOC and $\mathrm{BOD}$ reduction during the cultivation of Chlorella spp. in CML

The variation of $\mathrm{Cl}^{-}, \mathrm{PO}_{4}^{3-}, \mathrm{SO}_{4}{ }^{2-}, \mathrm{NO}_{2}^{-}$, and $\mathrm{NO}_{3}{ }^{-}$concentrations throughout the growth of Chlorella spp. in CML is presented in Table 1.

The $\mathrm{Cl}^{-}$concentration remained almost constant during the cultivation period. At the beginning of the experiment, the $\mathrm{PO}_{4}{ }^{3-}$ concentration was 109 $\mathrm{mg} / \mathrm{L}$. Notably, the $\mathrm{PO}_{4}{ }^{3-}$ concentration decreased considerably to $74 \mathrm{mg} / \mathrm{L}$ (3 day of cultivation), and then slowly increased up to $94.2 \mathrm{mg} / \mathrm{L}$ (day 15). Similar observations, in the case of phosphorus, were previously reported using activated sludge or bacteria [15]. Some bacteria possess the ability to assimilate and store the phosphate (as polyphosphates) under aerobic conditions. Under anaerobic conditions, the phosphate is released into the medium [15]. 
ZAMFIRA DINCĂ, MARIA-ALEXANDRA HOAGHIA, ANAMARIA-IULIA TÖRÖK, ENIKO KOVACS, OANA CADAR, EMILIA NEAG, CECILIA ROMAN

Table 1. Variation of $\mathrm{Cl}^{-}, \mathrm{PO}_{4}{ }^{3-}, \mathrm{SO}_{4}{ }^{2-}, \mathrm{NO}_{2}^{-}$, and $\mathrm{NO}_{3}{ }^{-}$concentrations throughout the growth of Chlorella spp. in CML

\begin{tabular}{|c|c|c|c|c|c|}
\hline $\begin{array}{c}\text { Element } \\
\text { (mg/L) }\end{array}$ & Day 3 & Day 6 & Day 9 & Day 12 & Day 15 \\
\hline $\mathbf{C l}^{-}$ & 34.2 & 34.2 & 34.0 & 33.8 & 33.4 \\
\hline $\mathbf{P O}_{4}{ }^{3-}$ & 74.0 & 78.0 & 88.2 & 90.8 & 94.2 \\
\hline $\mathbf{S O}_{4}{ }^{2-}$ & 40.0 & 40.2 & 41.6 & 42.2 & 42.8 \\
\hline $\mathrm{NO}_{2}{ }^{-}$ & $<0.05$ & $<0.05$ & $<0.05$ & $<0.05$ & $<0.05$ \\
\hline $\mathrm{NO}_{3}{ }^{-}$ & 2.40 & 1.14 & 1.16 & 1.10 & 1.02 \\
\hline
\end{tabular}

The $\mathrm{SO}_{4}{ }^{2-}$ concentration showed a slight increase from $31.3 \mathrm{mg} / \mathrm{L}$ to 42.8 $\mathrm{mg} / \mathrm{L}$ (day 15). During the microalgae growth, the $\mathrm{NO}_{2}{ }^{-}$concentration was below the analytical method's measuring range level $(<0.05 \mathrm{mg} / \mathrm{L})$, while the concentration of $\mathrm{NO}_{3}{ }^{-}$increased. The increase of $\mathrm{NO}_{3}{ }^{-}$concentration during the cultivation period indicates the presence of nitrifying microorganisms [16]. A similar trend was reported previously by Vargas et al. [16], when the capability of a consortium of nitrifying bacteria and microalgae to tolerate low dissolved oxygen concentrations using aerobic sludge from wastewater treatment plants was investigated [16]. Nitrogen is an essential component to living organisms and can be found at different oxidation states. Nitrogen is converted into $\mathrm{NH}_{4}{ }^{+}$, which is generated by a reduction process. Further, $\mathrm{NH}_{4}{ }^{+}$is converted to nitrite $\left(\mathrm{NO}_{2}{ }^{-}\right)$by nitrifying bacteria and then to nitrate $\left(\mathrm{NO}_{3}{ }^{-}\right)[17,18]$.

\section{Elemental composition}

The carbon $(\mathrm{C})$, hydrogen $(\mathrm{H})$, nitrogen $(\mathrm{N})$ sulphur $(\mathrm{S})$ and oxygen (O) content of biomass obtained after 15 days of cultivation can be seen in Table 2.

Table 2. The elemental composition of biomass obtained after 15 days of cultivation in CML

\begin{tabular}{|l|l|l|l|l|l|l|l|}
\hline \multicolumn{2}{|c}{} & $\begin{array}{l}\mathbf{N} \\
(\%)\end{array}$ & $\begin{array}{l}\mathbf{C} \\
\mathbf{( \% )}\end{array}$ & $\begin{array}{l}\mathbf{H} \\
\mathbf{( \% )}\end{array}$ & $\begin{array}{l}\mathbf{O} \\
(\mathbf{\%})\end{array}$ & $\mathbf{C / N}$ & $\begin{array}{c}\text { Protein } \\
(\%)\end{array}$ \\
\hline Control & & 7.38 & 42.32 & 6.04 & 44.25 & 5.74 & 46.12 \\
\hline \multirow{4}{*}{ CML } & day 3 & 11.97 & 42.18 & 6.32 & 39.52 & 3.52 & 74.79 \\
\cline { 2 - 8 } & day 6 & 10.77 & 44.16 & 6.39 & 38.66 & 4.10 & 67.33 \\
\cline { 2 - 8 } & day 9 & 9.92 & 45.16 & 6.23 & 38.67 & 4.55 & 62.02 \\
\cline { 2 - 8 } & day 12 & 10.14 & 44.52 & 6.47 & 38.85 & 4.39 & 63.38 \\
\cline { 2 - 8 } & day 15 & 9.99 & 45.69 & 6.30 & 38.01 & 4.58 & 62.41 \\
\hline
\end{tabular}


After the treatment of $\mathrm{CML}$, high $\mathrm{N}$ and $\mathrm{C}$ contents were found in the microalgal biomass when compared with the control biomass. During the cultivation period, the $\mathrm{N}$ and $\mathrm{C}$ contents ranged from 9.92 to $11.97 \%$ and from 42.18 to $45.69 \%$, respectively. The $\mathrm{H}$ content remained constant, around $6.0-6.9 \%$, while the $\mathrm{S}$ content was below $0.01 \%$. The $\mathrm{O}$ content slowly decreased during the cultivation in CML.

Changes in protein contents were observed during the cultivation period. High protein contents were obtained in the biomass grown in CML in comparison with the control biomass (46.12\%). A maximum protein content of $74.79 \%$ (day 3 ) was obtained. On days 9,12 and 15, the protein content of microalgal biomass was in average $62.6 \%$. Nitrogen is mainly associated with proteins [19]. Generally, Chlorella contains high protein contents around 42-58 \% (dry weight) [20], that are similar to the values found in Chlorella pyrenoidosa (57\%) and Chlorella vulgaris (51-58\%) [21]. The $\mathrm{C} / \mathrm{N}$ ratio is an indicator for bioconversion reactions [22]. The control biomass had a $\mathrm{C} / \mathrm{N}$ ratio of 5.74 , while the biomass grown in $\mathrm{CML}$ had poor $\mathrm{C} / \mathrm{N}$ ratios. The $\mathrm{C} / \mathrm{N}$ ratio varied from 3.52 to 4.58 in the biomass grown in CML. The obtained results are in good agreement with those reported previously for Chlorella sp. $(44.5 \% \mathrm{C}, 6.2 \% \mathrm{H}, 9.6 \% \mathrm{~N}$ and a $\mathrm{C} / \mathrm{N}$ ratio of 4.63$)$ [22].

\section{CONCLUSIONS}

Chlorella spp. was grown in a nutrient-rich medium, namely in CML. Preliminary investigations showed that, during the growth period, a decrease of BOD and TOC concentrations was observed, indicating that the microalgal biomass used the carbon source from the CML for their growth, while the aerobic microorganisms were able to break down the organic material from the medium. When compared with the control biomass, cultivation in CML medium increased protein accumulation in the microalgal biomass. Further investigations on the microalgal adaptation to CML conditions are needed in order to better understand the process involved during the assimilation of the nutrients available in the growth medium.

\section{EXPERIMENTAL SECTION}

\section{Poultry manure extract}

$200 \mathrm{~g}$ of chicken manure were immersed in $2000 \mathrm{~mL}$ distilled water, stirred gently at room temperature for $24 \mathrm{~h}$ and filtered using Whatman filter paper to remove the non-soluble particles. The resulting CML was used for the cultivation of Chlorella spp. The main characteristics of CML are shown in Table 3. 
ZAMFIRA DINCĂ, MARIA-ALEXANDRA HOAGHIA, ANAMARIA-IULIA TÖRÖK, ENIKO KOVACS, OANA CADAR, EMILIA NEAG, CECILIA ROMAN

Table 3. Characteristics of CML used for Chlorella spp. cultivation

\begin{tabular}{|c|c|c|}
\hline Parameter & Units & $\mathbf{C M L}$ \\
\hline $\mathbf{p H}$ & & 6.80 \\
\hline Conductivity & $\mu \mathrm{S} / \mathrm{cm}$ & 907 \\
\hline $\mathrm{BOD}$ & $\mathrm{mgO} / \mathrm{L}$ & 422 \\
\hline $\mathrm{TOC}$ & $\mathrm{mg} / \mathrm{L}$ & 448 \\
\hline $\mathbf{C l}^{-}$ & $\mathrm{mg} / \mathrm{L}$ & 34.2 \\
\hline $\mathbf{P O}_{4}{ }^{3-}$ & $\mathrm{mg} / \mathrm{L}$ & 109 \\
\hline $\mathbf{S O}_{4}{ }^{2-}$ & $\mathrm{mg} / \mathrm{L}$ & 31.3 \\
\hline $\mathrm{NO}_{2}{ }^{-}$ & $\mathrm{mg} / \mathrm{L}$ & 0.05 \\
\hline $\mathrm{NO}_{3}{ }^{-}$ & $\mathrm{mg} / \mathrm{L}$ & 0.20 \\
\hline
\end{tabular}

\section{Experiment design}

Chlorella spp. was inoculated at 1:10 (v/v) ratio in CML and BG-11 medium. The cultures grown in BG-11 medium were considered the control samples. The cultivation in CLM and BG-11 medium was carried out for 15 days at a temperature of $25 \pm 1^{\circ} \mathrm{C}$, under artificial illumination of 1200 lux for $12 / 12 \mathrm{~h}$ day/night cycle, at laboratory scale.

\section{Analysis}

Prior to the analysis, the samples were filtered to remove the Chlorella spp. cells. pH and conductivity of the culture medium throughout the growth period (day 3, 6, 9, 12 and 15) were determined using a Seven Excellence multiparameter, Mettler Toledo, Switzerland. BOD was determined using an oxygen meter WTW, INOLAB 740 electrode with StirrOxG sensor, while TOC values were determined using a multi N/C 2100S Analytik Jena analyzer.

The concentrations of $\mathrm{Cl}^{-}, \mathrm{PO}_{4}{ }^{3-}, \mathrm{SO}_{4}{ }^{2-}, \mathrm{NO}_{2}{ }^{-}$and $\mathrm{NO}_{3}{ }^{-}$were analyzed with an ion chromatograph (761 IC, Metrohm, Switzerland) after the filtration of the samples with $0.45 \mu \mathrm{m}$ cellulose acetate membrane filters and dilution with ultrapure water. Quality assurance was performed by measuring the standard solutions with known concentrations supplied by Merck, blanks and two to three replicates. The $\mathrm{C}, \mathrm{H}, \mathrm{N}$ and $\mathrm{S}$ content of biomass was determined by a Flash EA $2000 \mathrm{CHNS/O}$ analyzer (Thermo Fisher Scientific, USA). The $O$ content was determined by difference and the protein content was calculated using the nitrogen-to-protein conversion factor. 


\section{ACKNOWLEDGMENTS}

This work was funded by the Core Program, under the support of ANCS, project no. PN 19-18.01.01 (contract no. 18N/08.02.2019). The funder had no role in the design of the study; in the collection, analysis and interpretation of data; in the writing of the manuscript, and in the decision to submit the article for publication.

\section{REFERENCES}

1. FAO, $2018 \mathrm{http}: / / \mathrm{www}$. fao.org/3//8153EN/i8153en.pdf

2. Eurostat, $2020 \mathrm{https}: / /$ ec.europa.eu/eurostat/statistics-explained/index.php?title= Agricultural_production_-_livestock_and_meat\&oldid=470510\#Poultry

3. X.T. Han; N. Rusconi; P. Ali; K. Pagkatipunan; F. Chen; Green and Sustainable Chemistry, 2017, 7, 101-113

4. H.M. Singh; V.V. Tyagi; R. Kothari; R. Azam; P.S. Slathia; B. Singh; Bioresour. Technol., 2020, 316, 123850

5. P. Smith et al. How much land-based greenhouse gas mitigation can be achieved without compromising food security and environmental goals?, In Global Change Biology, John Wiley \& Sons Ltd, 2013, Volume 19, Issue 8, pp. 2285-2302

6. Y. Alba Reyes; E.L. Barrera; K.-k. Cheng; J. Environ. Chem. Eng., 2021, 9, 104695

7. G. Markou; F. Monlau; Nutrient recycling for sustainable production of algal biofuels, in Biomass, Biofuels, Biochemicals, Biofuels from Algae (Second Edition), A. Pandey, J.-S. Chang, C.R. Soccol, D.-J. Lee, Y. Chisti Eds.; Elsevier, 2019, Chapter 6, pp. 109-133

8. A.J. Ashworth; J.P. Chastain; P.A. Moore Jr.; Nutrient Characteristics of Poultry Manure and Litter, in Animal Manure: Production, Characteristics, Environmental Concerns, and Management, Volume 67, H.M. Waldrip, P.H. Pagliari, Z. He Eds.; American Society of Agronomy, Inc. Soil Science Society of America, Inc., 2020, pp. 63-87

9. M.M. Amanullah; S. Sekar; P. Muthukrishnan; Asian Journal of Plant Sciences, 2010, 9, 172-182

10. R. Li; N. Duan; Y. Zhang; Z. Liu; B. Li; D. Zhang; H. Lu; T. Dong; Waste Manage., 2017, 70, 247-254,

11. T. Moungmoon; C. Chaichana; C. Pumas; W. Pathom-aree; K. Ruangrit; J. Pekkoh; Sci. Total Environ., 2020, 714, 136577

12. R. Malolan; R.S.Jayaraman; S. Adithya; J. Arun; K.P. Gopinath; P.S. Sundar Rajan; O. Nasif; W. Kim; M. Govarthanan; Chemosphere, 2021, 266,128963 
ZAMFIRA DINCĂ, MARIA-ALEXANDRA HOAGHIA, ANAMARIA-IULIA TÖRÖK, ENIKO KOVACS, OANA CADAR, EMILIA NEAG, CECILIA ROMAN

13. M. Altunoz; O. Pirrotta; L. Forti; G. Allesina; S. Pedrazzi; O. Obali; P. Tartarini; L. Arru; Bioresour. Technol., 2017, 244, Part 2, 1261-1268

14. S.S.M. Mostafa; E.A. Shalaby; G.I. Mahmoud, Not. Sci. Biol., 2012, 4(1), 56-65

15. S. Zhu; L. Qin; P. Feng; C. Shang; Z. Wang; Z. Yuan; Bioresour. Technol., 2019, 274, 313-320.

16. G. Vargas; A. Donoso-Bravo; C. Vergara; G. Ruiz-Filippi, Electron. J. Biotechnol., 2016, 23, 63-68.

17. A. Kumar; S. Bera, Bioresour. Technol. Rep., 2020, 12, 100584.

18. M. Holtappels; G. Lavik; M.M. Jensen; M.M.M. Kuypers; 15N-Labeling Experiments to Dissect the Contributions of Heterotrophic Denitrification and Anammox to Nitrogen Removal in the OMZ Waters of the Ocean, in Methods in Enzymology; M. G. Klotz Ed.; Academic Press, 2011, Chapter 10, Volume 486, pp. 223-251

19. A. Sánchez-Bayo; V. Morales; R. Rodríguez; G. Vicente Crespo; L. F. Bautista; Preprints, 2019, 110108, doi: 10.20944/preprints201911.0108.v1.

20. U.D. Enyidi; Fishes, 2017, 2, 17.

21. T. Bito; E. Okumura; M. Fujishima; F. Watanabe; Nutrients., 2020, 12, 2524.

22. L. Rendón-Castrillón; M. Ramírez-Carmona; C. Ocampo-López; R. GiraldoAristizabal, Braz. J. Biol., 2021, 81(1), 202-209. 